\title{
Review \\ Effect of Aging on Homeostasis in the Soft Tissue of the Periodontium: A Narrative Review
}

\author{
Yu Gyung Kim ${ }^{1}$, Sang Min Lee ${ }^{1}$, Sungeun Bae ${ }^{1}$, Taejun Park ${ }^{1}$, Hyeonjin Kim ${ }^{1}$, Yujeong Jang ${ }^{1}$, Keonwoo Moon ${ }^{1}$, \\ Hyungmin Kim ${ }^{1}$, Kwangmin Lee ${ }^{1}$, Joonyoung Park ${ }^{1}$, Jin-Seok Byun ${ }^{2, *}$ and Do-Yeon Kim ${ }^{3, *(D)}$
}

1 Department of Pharmacology, School of Dentistry, Kyungpook National University, Daegu 41940, Korea; cosmos0468@naver.com (Y.G.K.); leeyang2324@naver.com (S.M.L.); em5161@naver.com (S.B.); parktj@gmail.com (T.P.); twdt92@gmail.com (H.K.); yjeong07@naver.com (Y.J.); moons2317@naver.com (K.M.); hyuongmin@naver.com (H.K.); mgkd200@naver.com (K.L.); junfriend777@hanmail.net (J.P.)

2 Department of Oral Medicine, School of Dentistry, Kyungpook National University, Daegu 41940, Korea

3 Department of Pharmacology, School of Dentistry, Brain Science and Engineering Institute, Kyungpook National University, Daegu 41940, Korea

* Correspondence: jsbyun@knu.ac.kr (J.-S.B.); dykim82@knu.ac.kr (D.-Y.K.); Tel.: +82-53-600-7323 (J.-S.B.); +82-53-660-6880 (D.-Y.K.)

check for updates

Citation: Kim, Y.G.; Lee, S.M.; Bae, S.; Park, T.; Kim, H.; Jang, Y.; Moon K.; Kim, H.; Lee, K.; Park, J.; et al. Effect of Aging on Homeostasis in the Soft Tissue of the Periodontium: A Narrative Review. J. Pers. Med. 2021, 11, 58. https://doi.org/10.3390/ jpm11010058

Received: 16 December 2020

Accepted: 15 January 2021

Published: 18 January 2021

Publisher's Note: MDPI stays neutral with regard to jurisdictional claims in published maps and institutional affiliations.

Copyright: (c) 2021 by the authors. Licensee MDPI, Basel, Switzerland. This article is an open access article distributed under the terms and conditions of the Creative Commons Attribution (CC BY) license (https:/ / creativecommons.org/licenses/by/ $4.0 /)$.

\begin{abstract}
Aging is characterized by a progressive decline or loss of physiological functions, leading to increased susceptibility to disease or death. Several aging hallmarks, including genomic instability, cellular senescence, and mitochondrial dysfunction, have been suggested, which often lead to the numerous aging disorders. The periodontium, a complex structure surrounding and supporting the teeth, is composed of the gingiva, periodontal ligament, cementum, and alveolar bone. Supportive and protective roles of the periodontium are very critical to sustain life, but the periodontium undergoes morphological and physiological changes with age. In this review, we summarize the current knowledge of molecular and cellular physiological changes in the periodontium, by focusing on soft tissues including gingiva and periodontal ligament.
\end{abstract}

Keywords: aging; periodontium; gingiva; periodontal ligament; MMP

\section{Introduction}

Aging is defined as a progressive decline or loss of intrinsic physiological functions, leading to a decrease in reproductive and survival rates [1]. Although death is inevitable to human, individuals have craved a way of delaying the aging process and extending the lifespan. In this regard, aging research has identified critical risk factors and treatment strategies for major age-related pathologies including cardiovascular diseases, neurodegenerative disorders, cancers, and other chronic diseases [2]. In addition, recent studies suggest several promising interventions, such as regulating nutrient sensing, controlling cellular senescence, and balancing the gut microbiome [3].

Indeed, some pharmacological approaches were proven to slow down age-dependent functional decline. For example, rapamycin extended the median and maximal lifespan of mice when fed beginning at 20 months of age [4]. Rapamycin seems to extend healthspan as well as lifespan through reversing age-related vascular dysfunction and oxidative stress [5], rejuvenating oral health [6], and ameliorating age-dependent cognitive deficits [7]. Interestingly, recent clinical study showed that topical rapamycin treatment efficiently suppressed human skin aging [8]. Resveratrol, a polyphenol found in red wine, has been also proven to prolong lifespan of model organisms including yeast, nematode worms, fruit flies, and rodents [9-11]. Resveratrol additionally showed the protective effects in several mouse models of age-dependent neurodegenerative disorders $[12,13]$. Recently, resveratrol was reported to enhance cognitive and cerebrovascular functions in postmenopausal women [14]. Metformin, the first-line medication prescribed for type 2 diabetes, was also found to significantly prolong lifespan in worms by up to $36 \%[15,16]$. However, whether 
these pharmacological interventions extend the lifespan and/or healthspan in humans needs to be validated further.

Aging research proposed critical aging hallmarks that describe common denominators among species, including genomic instability, cellular senescence, and mitochondrial dysfunction [2]. During aging, genetic damages are accumulated and gene expression patterns are continuously changed [17]. These alterations are mediated by extracellular chemical/biological stimuli, as well as by intracellular replicative/oxidative stress. Genetic disintegrity and abnormal gene expression changes often lead to numerous aging disorders [18]. Aging-inducing factors also trigger cellular senescence which can be dependent on or independent of telomere shortening. Cellular senescence refers to the irreversible loss of cell growth capacity, which commonly accompanies peculiar phenotypic alterations. Of note, frequencies of senescent cells are dramatically increased in several tissues, when comparing young and old mice. For example, approximately $8 \%$ of senescent cells were observed in young mice liver but the percentage of senescent hepatocytes are increased to $17 \%$ in old mice. Additionally, in the spleen, young mice have only $7 \%$ of senescent lymphocytes but aged mice have $25 \%$ of senescent lymphocytes [19]. Accumulation of senescent cells is also observed in humans in several tissues [20]. When the cellular senescence process is hyperactivated, it leads to downregulation of tissue function and repair, upregulation of inflammatory responses, reduction of cell renewal, and exhaustion of stem cells. Aging also affects the efficiency of the respiratory chain in the mitochondria. Furthermore, mitochondrial dysregulation can expedite aging [21]. Mitochondrial decline can affect apoptotic signaling and upregulated unwanted inflammatory reactions [22]. In addition, inefficient biogenesis of mitochondria with age causes disruption in energy metabolism systemically.

The periodontium, a complex structure surrounding and supporting the teeth, is composed of the gingiva, periodontal ligament, cementum, and alveolar bone [23]. The primary roles of the periodontium are to support attachment for the tooth to the bone of the jaw and help the tooth to endure the stress of mastication. In addition, the periodontium guards the underlying structure against pathogenic oral microflora and protects the blood vessels and nerves from injury. Dynamic remodeling in the periodontium is essential for orthodontic tooth movement, improved occlusion, and decreased tooth wear [24,25]. As a functional biological system, the periodontium undergoes morphological and physiological changes with age. In this review, we summarize the current knowledge of molecular and cellular physiological changes in the periodontium, by focusing on soft tissues including gingiva and periodontal ligament.

\section{Anatomical and Physiological Homeostasis in the Gingiva}

The gingiva is located on the external surface of the periodontium and covers alveolar bone and tooth root. The gingiva is composed of an outer epithelial layer and an underlying connective tissue, called lamina propria, and the epithelium is histologically subdivided into at least three sections (the oral epithelium, the sulcular epithelium, and the junctional epithelium). While the gingival epithelium consists of several cell types, including keratinocytes, melanocytes, Langerhans cells, and Merkel cells, the lamina propria is mostly filled with collagen fibers, vessels, nerves, and matrix [26]. Compared to the epithelial layer, relatively small quantity of cells, such as fibroblasts and innate immune cells, reside in the connective tissue.

The oral epithelium is a keratinized oral mucosa and it is the thickest $(0.2-0.3 \mathrm{~mm}$ in thickness on average) layer among the gingival epithelium. The sulcular epithelium is a thin, non-keratinized (but often parakeratinized situationally) epithelial lining of the gingival sulcus. The oral and sulcular epithelium primarily perform protective and defensive roles. However, because the sulcular epithelium may act as a semi-permeable membrane through which pathogenic bacterial byproduct penetrate, it can be involved in the detection of bacterial assault and initiation of immune responses. In contrast, the junctional epithelium, non-keratinized cell layer adhering to the tooth surface, serves mul- 
tiple functions. The junctional epithelium mediates the epithelial attachment to the tooth surface and basement membrane facing the connective tissue through hemidesmosomes and the extracellular matrix [27]. The junctional epithelium also serves as the front-line of defense system against injurious bacterial infection by expressing anti-microbial factors such as secretory leukocyte protease inhibitor (Slpi) [28] and S100A9 [29]. In addition, the junctional epithelium cells constitutively express chemokines and cytokines including keratinocyte-derived chemokine (KC/CXCL1) and macrophage inflammatory protein-2 (MIP-2/CXCL2), as a result, polymorphonuclear leukocytes are heavily infiltrated into the junctional epithelium, which provides maintenance of physiological homeostasis as well as anti-pathogenic defense [30]. Given that the junctional epithelium shows high turnover rate, it can also contribute to tissue regeneration and dental plaque suppression [31].

The gingival connective tissue performs critical functions in the protection of cement root and alveolar bone [26]. The connective tissue also shows rapid turnover, it has a marked capacity of healing and regeneration [32]. In gingival connective tissue, fibroblasts perform central roles in the development, homeostatic maintenance, and repair. Fibroblasts constitute approximately two-thirds of cell population in the gingival connective tissue, and synthesize/secrete components of the extracellular matrix such as collagen, elastin, and glycoproteins. Fibroblasts induce proliferation of connective tissue cells by expressing platelet-derived growth factor (PDGF) [33], and following injury to tissues, fibroblasts migrate to damaged sites and mediate tissue repair/regeneration, in cooperation with inflammatory cells [34].

Aging seems to negatively affect homeostatic regulation in gingiva (Figure 1). Mounting evidence demonstrated that the width of attached gingiva increases with age, mirroring the riskiness of disease incidence on the periodontium [35,36]. Gingival recession caused by accumulated mechanical trauma or gingivitis could induce the loss of attachment, in an age-dependent manner [37]. Cáceres et al. compared several physiological aspects of young and aged gingiva, with primary cultures of gingival fibroblasts and rat models. Importantly, gingival fibroblasts from aged individuals displayed reduced capacities of cell proliferation and migration, altered myofibroblastic differentiation, and diminished collagen remodeling, indicating that the capability of gingival repair is retarded with age. Deficiencies in gingival wound-healing were additionally confirmed with a rat model [38]. Interestingly, probably for compensating reduced proliferative capacity, gingival tissues from aged animals showed higher anti-apoptotic and lower pro-apoptotic gene expression compared with gingival tissues from young animals [39].

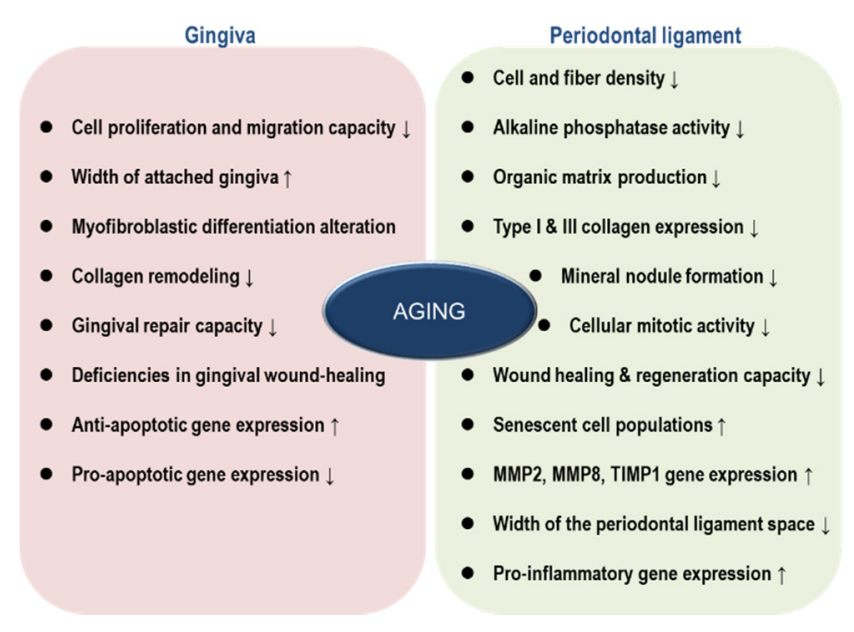

Figure 1. Physiological and biochemical changes in gingiva and periodontal ligament during aging.

\section{Anatomical and Physiological Homeostasis in the Periodontal Ligament}

The periodontal ligament provides the supporting connection of the cementum covering the tooth root to the inner socket of the alveolar bone through bundles of type I collagen named Sharpey's fibers [40]. The periodontal ligament also helps to fuel vascular supply 
and nutrients to the cementum and the alveolar bone. The periodontal ligament consists of numerous cell types including fibroblasts, progenitor cells, epithelial cells, blood cells [23]. In addition, cementoblasts are lined at the cementum interface, while bone-associated cells, such as osteoblasts, osteoclasts, and odontoblasts, are located along the alveolar bone. Intercellularly, poroelastic substances composed of an organic matrix filled with a fluid component inside the periodontal ligament sense applied physical forces in the bone and act as an elastic limit to prevent tooth damage [41,42].

In the periodontal ligament, fibroblasts are the predominant cell type, making up approximately $25-30 \%$ of the volume space and $50-60 \%$ of the total cellularity [43]. Fibroblasts perform central roles in repair and remodeling of the periodontal ligament by generating the collagen fibers. Given that fibroblasts have the capacity to proliferate rapidly and migrate dynamically, these cell populations show a critical function during periodontal wound healing. Interestingly, when fibroblasts are exposed to physical or biochemical stimuli, they are able to differentiate into osteoblasts and/or cementoblasts by inducing c-fos mRNA expression and/or activating the ERK/JNK pathway $[44,45]$. The periodontal ligament fibroblasts can also be involved in osteoclastogenesis [46], suggesting the prominent role of the periodontal ligament in periodontium homeostasis.

Defense cells, including macrophages, mast cells, and eosinophils, also exist in the periodontal ligament. The primary role of these cells is the protection of periodontium by phagocytizing invading pathogens and dead cells. However, they also mediate the proliferation of fibroblasts and endothelial cells by secreting growth factors and cytokines. Another important cell type residing in the periodontal ligament is stem cell. The existence of a putative stem-cell population inside the periodontal ligament was first identified in 2004 [47]. The periodontal ligament stem cells represented mesenchymal stem cell traits such as clonogenicity, expression of specific markers STRO-1 and CD146/MUC18, and the capacity of differentiation into cementoblast, osteoblast, adipocyte, odontoblast, and fibroblast. Recent evidence additionally identified that epithelial stem cells also exist in the periodontal ligament [48].

A modest to severe functional reduction in the periodontal ligament accompanies aging. Earlier observation indicated that aging negatively influenced cell and fiber density, organic matrix production, and cellular mitotic activity in the periodontal ligament [49]. In line with these results, Benatti et al. showed that cell proliferation, mineral nodule formation, and mRNA expressions of type I and III collagen were downregulated over the lifespan [50]. The decline of proliferative capacity by aging ultimately leads to impaired wound healing and reduced tissue regeneration. Furthermore, senescent cell populations are progressively accumulated and the activity of AP-1 transcription factor is gradually decreased with age, due to a loss of c-fos expression [51]. On the other hand, mRNA levels of matrix metalloproteinase (MMP)-2, MMP-8, and tissue inhibitor matrix metalloproteinase (TIMP)-1 were upregulated, suggesting that extracellular matrix might be easily degraded with age.

Aged periodontal ligament cells express higher level of pro-inflammatory genes including osteoprotegerin, IL-1 $\beta$, and IL-6 [52]. Considering that osteoclast activity is regulated by osteoprotegerin and RANKL [53], it is not surprising that bone turnover is increased with age [54]. Aged periodontal ligament cells also show lower alkaline phosphatase activity, which means reduced osteogenesis and calcification [55]. Consistently, osteoblastic gene expression gradually diminishes with age [56].

Lim et al. also showed that the width of the periodontal ligament space is reduced over the lifespan [54]. This phenomenon can be explained by the accumulation of mineralized tissue and/or atrophy of collagen fibers with age. Narrower diameter of the periodontal ligament can increase the risk of tooth or bone fracture because occlusal forces will be converged on a smaller area. 


\section{Molecular Profile Changes with Age in the Periodontium}

\subsection{Inducible Nitric Oxide Synthase}

According to the oxidative stress theory of aging, accumulation of oxidative damage by reactive oxygen and nitrogen species (RONS) contributes to the process of normal aging as well as the development of pathological conditions [57]. At a molecular level, excessive levels of exogenous or endogenous RONS result in oxidation of intracellular components, such as DNA, RNA, protein, and lipid [58]. Oxidative modification to these macromolecules causes disturbance of normal cellular physiological activities and impairment of homeostatic maintenance including mitochondrial integrity and proteostasis, which can ultimately lead to cell dysfunction or even cell death [59].

Nitric oxide (NO), a diatomic free radical and weak oxidant [60], is generated from L-arginine by three major isoforms of nitric oxide synthase (NOS): endothelial NOS (eNOS), neuronal NOS (nNOS), and inducible NOS (iNOS) [57]. Physiological levels of NO show prominent cellular functions via homeostatic redox-sensitive signaling pathways [61]. However, uncontrolled production of $\mathrm{NO}$ can participate in a variety of disease processes. When NO reacts with the superoxide anion radical $\left(\mathrm{O}^{2-}\right)$, peroxynitrite $\left(\mathrm{ONOO}^{-}\right)$is actively generated and peroxynitrite mediates the nitration of target proteins at tyrosine residue. Peroxynitrite and protein tyrosine nitration are associated to the normal aging process and onset of various diseases including atherosclerosis [62], inflammatory injury [63], and neurodegeneration [64].

While the constitutive NOS isoforms, eNOS and nNOS, generate short-lasting and low levels of NO, iNOS produces long-lasting and larger quantities of NO [65]. In this reason, the contribution of iNOS to normal aging and pathological process in the periodontium has been studied. Regardless of exogenous stimuli, gingival fibroblasts obtained from aged human secreted more NO than cells derived from younger human. Consistently, the basal mRNA level of iNOS was upregulated in aged gingival fibroblasts [66].

\subsection{Matrix Metalloproteinase (MMP)}

Extracellular matrix (ECM) is a non-cellular structure that provides a biochemical and biomechanical environment within which cells reside. In addition to providing supportive structure for cells, the ECM defines the boundary between tissues and regulates cellular physiologies and intra-/inter-cellular communication. Aging affects the composition and structural flexibility of ECM. Recently, Tanaka et al. analyzed plasma proteins of all age groups and identified $\sim 650$ age-associated proteins in which extracellular matrix-related proteins were enriched [67]. Another recent study demonstrated that abundance of hyaluronan, an ECM glycosaminoglycan, gradually decreased with age, leading to the alteration in biomechanical properties of ECM [68]. As a critical factor for skin moisture, hyaluronan preserves the hydration of skin, thereby suppresses skin aging. Hyaluronan is also involved in anti-inflammatory responses and anti-photoaging of skin [69]. In addition, hyaluronan has protective functions by inhibiting parasites invasion and tumor metastasis [70]. Furthermore, hyaluronan promotes wound healing, and the prolonged upregulation of hyaluronan is associated with scar-free repair [71]. Based on these positive roles, hyaluronan is now actively used in the dental field [72]. Therefore, aging accompanying with progressive decline of hyaluronan severely impairs proliferating and regenerative capacities of oral fibroblasts, resulting in downregulation of ECM production, disorganization of ECM architecture, and inefficient wound healing [73,74]. Indeed, accumulating clinical evidence reveals that wound healing capacity after biopsy or periodontal surgery is higher in younger individuals $[75,76]$.

MMPs are $\mathrm{Zn}^{2+}$ - and $\mathrm{Ca}^{2+}$-dependent proteases that have critical roles in diverse biological and pathological processes. In human, 23 different MMPs have been identified so far. Given that MMPs facilitate the disassembly of the ECM, they serve important roles in ECM homeostasis and remodeling. Notably, Kim et al. recently reported that alterations in MMPs expression would be highly responsible for gingival aging [77]. This study identified that mRNA levels of MMP-3, MMP-9, MMP-12, and MMP-13 were dramatically 
increased with age in gingival tissue, along with the upregulation of IL-1 $\beta$ expression. More interestingly, increased levels of MMPs and IL- $1 \beta$ would be linked to induced susceptibility to pathogenic infection in aged gingiva (Figure 2).

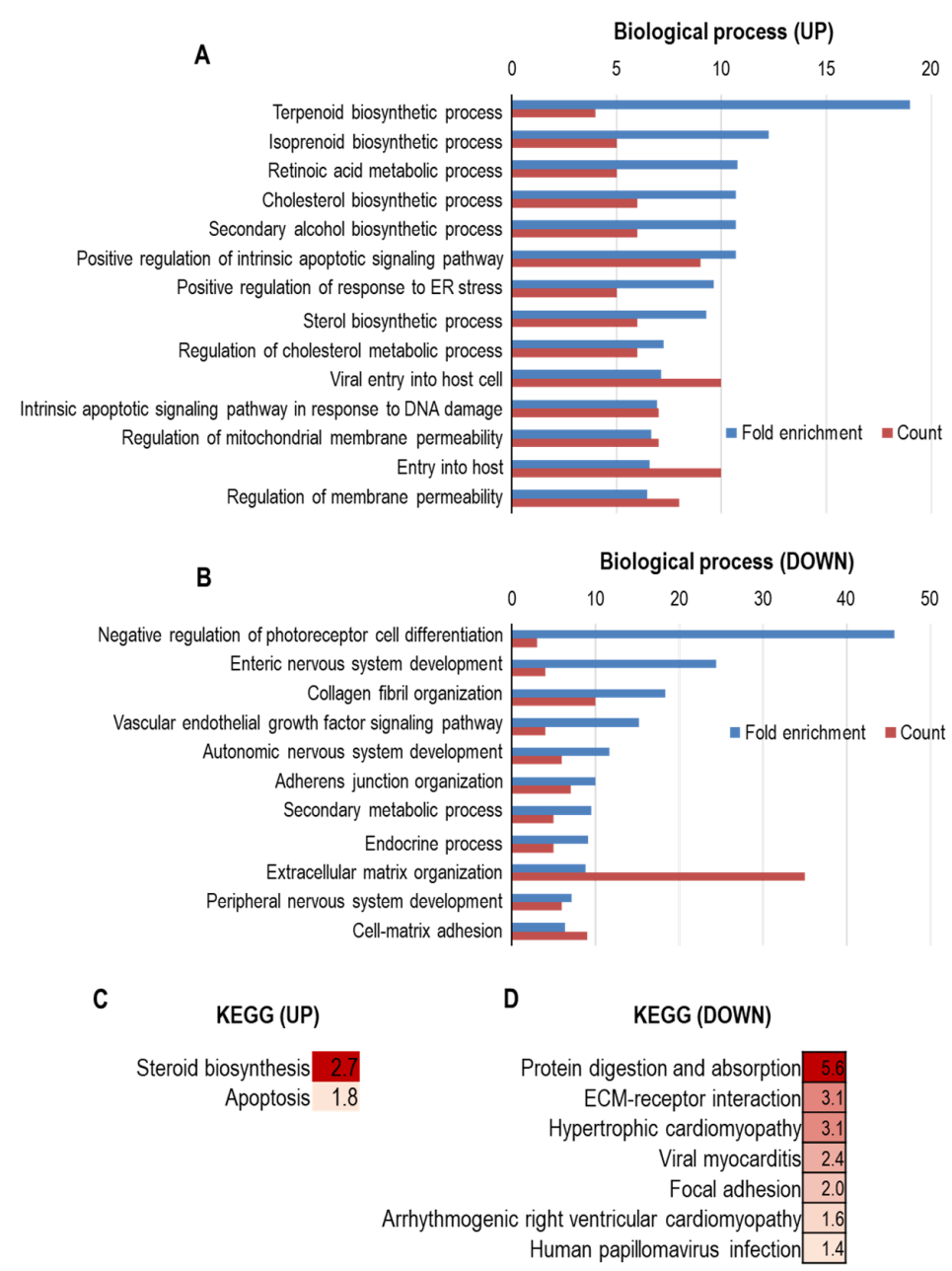

Figure 2. GO enrichment analysis and KEGG pathway enrichment analysis of differentially expressed genes by aging in human gingiva. (A-D) mRNA profiles of young and old human gingiva were extracted and analyzed from the NCBI Gene Expression Omnibus (GEO) profile database (GEO accession: GSE83382). Determination of upregulated genes during aging was based on fold-change of the expression level $>2$ and a $p$-value $<0.05$. Determination of downregulated genes was based on fold-change of the expression level $<0.5$ and a $p$-value $<0.05$. GO analysis of upregulated genes (A) and downregulated genes (B) was conducted by utilizing Gene Ontology resources [78-80]. KEGG pathway analysis of upregulated genes $(\mathbf{C})$ and downregulated genes $(\mathbf{D})$ was conducted by utilizing g:Profiler $[81,82]$. In (C,D), the color indicates the degree of statistical significance, and negative $\log 10$ of adjusted $\mathrm{p}$ values were presented in each box.

Considering that gingival tissues-derived MMP-3 contributes to the progression of adult periodontitis by activating MMP-8 and MMP-9 derived from crevicular fluid neutrophil [83], increased expression of MMPs would be responsible for age-related periodontal inflammation. Indeed, accumulating evidence has suggested the link between MMPs and periodontitis. MMP-8 and MMP-9 have been frequently found to be elevated in chronic or advanced periodontitis, assessing the potential of these MMPs as the most promising periodontitis biomarkers (Figure 3) [84,85]. Although expressed at a lesser degree, MMP13 has also involved in destructive periodontal disease [86,87]. These MMPs induce the secretion of pro-inflammatory cytokines, including TNF $\alpha$, IL-1 $\beta$, IL- 6 , and IL-12, in the periodontal tissues during periodontitis progression [88]. It has been repeatedly shown 
that local and systemic inflammatory responses were downregulated in MMP-8-deficient mice [89-91]. In addition, polymorphisms in MMP-1, MMP-3, MMP-8, and MMP-9 are associated with chronic periodontitis susceptibility $[92,93]$.

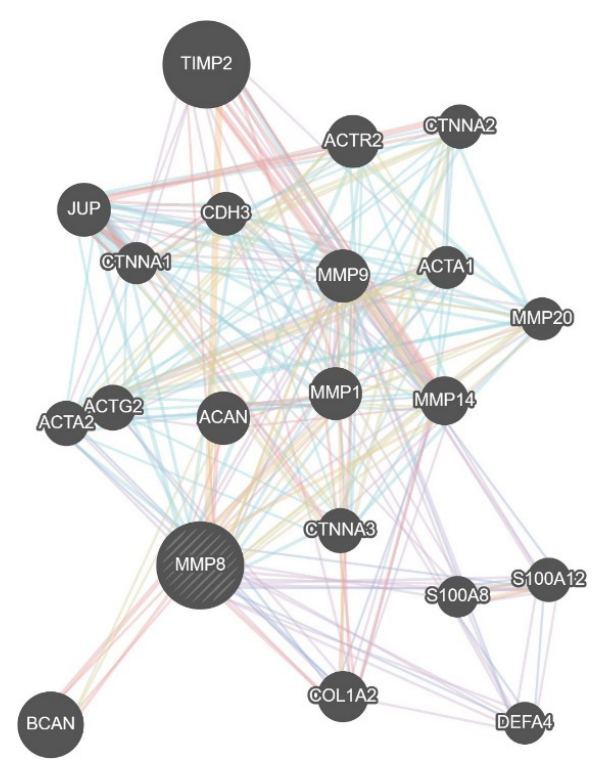

Figure 3. Biological network of MMP8 gene. The gene-gene interaction network of MMP8. The data were derived from the GeneMANIA database (https:/ /genemania.org/) [94].

\subsection{Others}

Many research groups keep identifying the change in molecular expression during aging. Grzibovskis et al. showed that expression level of basic fibroblast growth factor (bFGF) was significantly decreased with age [95]. As a well-known growth factor, bFGF regulates the proliferation, apoptosis, and regeneration of several cells/tissues, including gingiva and periodontal ligament $[96,97]$. More recently, it was reported that bFGF inhibits periodontal inflammation by suppressing CD40-mediated inflammatory signaling [98]. Based on the regenerative capacity of bFGF, many clinical trials were already performed to recuperate periodontal tissue which was disrupted by age or pathological conditions. In the phase II clinical trial, administration of recombinant human (rh)-bFGF clearly increased alveolar bone height [99]. In the following clinical trials, rh-bFGF significantly enhanced bone fill, but the increment of clinical attachment level was insufficient $[100,101]$. When rh-bFGF was treated with a $\beta$-tricalcium phosphate $(\beta$-TCP) scaffold carrier, clinical outcomes were improved, which were determined by the clinical attachment level and linear bone growth [102].

Several genes involved in the apoptotic pathway are differentially expressed with age. González et al. showed that young gingival tissue expresses pro-apoptotic genes more abundantly than adult or aged gingiva [39]. Specifically, TNF receptor 1, BH3 interacting domain death agonist (BID), the apoptotic peptidase activating factor 1 (APAF-1), and p53 are upregulated in younger gingiva. In contrast, anti-apoptotic genes, including phosphatidylinositol 3-kinase (PI3K) and IKB kinase (IKK), were expressed higher in adult or aged gingiva. These changes in molecular profile indicate that apoptotic processes show critical function in the homeostasis of the periodontium. Earlier evidence already demonstrated that adequate apoptotic signaling produces anti-inflammatory responses, and apoptosis impairment contributed to the development of chronic inflammatory diseases $[103,104]$. Consistently, it was shown that upregulated resistance to apoptosis, mediated by activation of the PI3K pathway, provided survival benefit to Porphyromonas gingivalis-infected oral epithelial cells, resulting in periodontitis pathogenesis [105]. The molecular link between apoptosis and aging needs to be precisely determined in further studies. 


\section{Physiological Changes with Age in the Periodontium}

\subsection{Responsiveness to Pathogens with Age}

Aging may directly or indirectly impact the responsiveness of host defenses against pathogens. Intrinsic aging of the skin and oral mucosa reduces the defense system to allow pathogens an easier entrance and colonization. As a result, aging promotes bacterial proliferation in the mouth, leading to the overgrowth of oral anaerobes [106]. In addition, aging influences the oral flora, showing that aged mice have less bacterial diversity when compared with young mice [107].

The susceptibility to destructive diseases occurred in the periodontium can be affected by aging. Healthy gingival fibroblasts normally serve as the first-line guardian against oral pathogens. However, aged gingival fibroblasts show increased susceptibility to bacterial infection. When exposed to Porphyromonas gingivalis, the gene expression pattern revealed large discrepancy between young and aged gingival fibroblasts [108]. Particularly, aged fibroblasts failed to upregulate IL-6 production against bacterial infection, mirroring the impairment of immune responses in old fibroblasts. Ahn et al. utilized another periodontal pathogen, Fusobacterium nucleatum, to compare transcriptome of senescent gingival fibroblasts with that of younger cells [109], and identified that five genes (ID1, KLF10, GADD45b, TM4SF1, and CSRNP1) were mostly induced in aged gingival fibroblasts, in response to Fusobacterium nucleatum (Figure 4). Following study would be required to determine the roles of these genes in age-dependent susceptibility to pathogens. Moreover, further detection of new oral pathogens and investigation of their roles in the onset and progression of age-related diseases are also required [110].

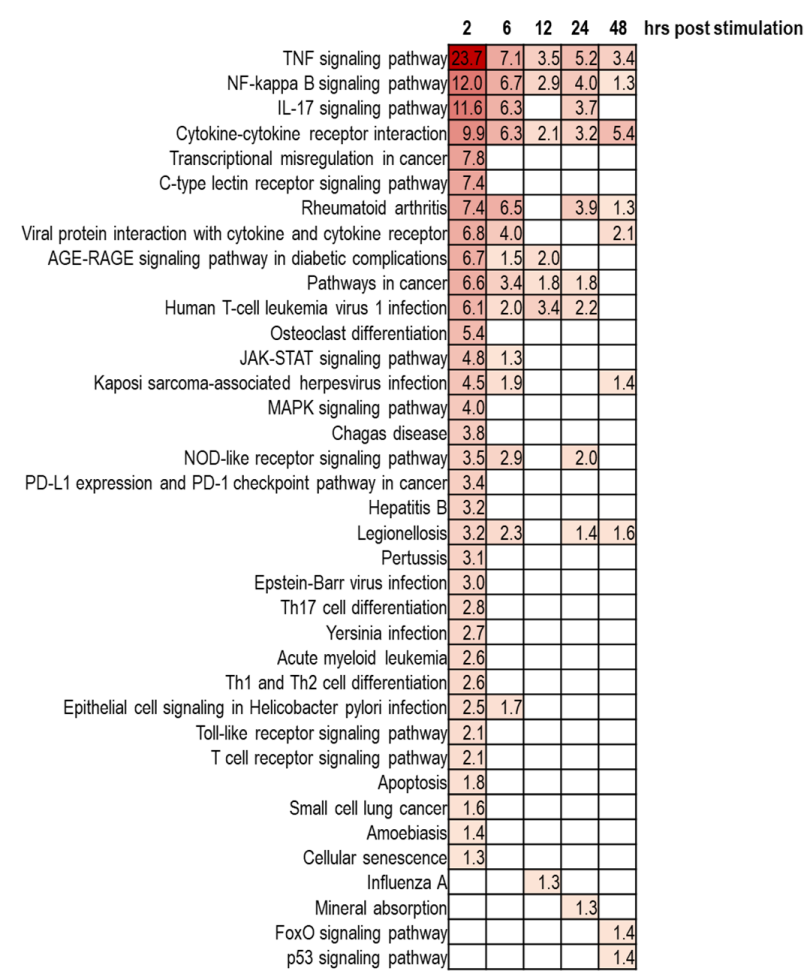

Figure 4. KEGG pathway enrichment analysis of upregulated genes by Fusobacterium nucleatum infection in human gingival fibroblasts. Gingival fibroblasts were infected with Fusobacterium nucleatum for 2, 6, 12, 24, and $48 \mathrm{~h}$, and KEGG pathway analysis was performed. The color indicates the degree of statistical significance, and negative $\log 10$ of adjusted $\mathrm{p}$ values were presented in each box. Data were extracted and analyzed from the NCBI GEO profile database (GEO accession: GSE118691) [111]. Determination of upregulated genes at each time point was based on fold-change of the expression level $>2$ and a $p$-value $<0.05$. 
Although whether saliva production and salivary flow rate are affected by age is still controversial [112,113], it has been repeatedly shown that morphologies of salivary glands change with age and atrophy of the acinar cells tends to be increased during aging $[114,115]$. Given that reduced salivary flow or xerostomia has been reported as side effects in more than 400 medications, including psychotropic analgesics, diuretic drugs, calcium antagonists, and anti-histamines, elderly people seem to be more afflicted with dry mouth symptoms. Considering the preventive roles of saliva, such as suppressing bacterial propagation and neutralizing acids released from pathogens, tendency of drug dependence in the elderly would contribute to increased susceptibility to oral pathogens in aged people [116].

\subsection{Drug-Influenced Alterations in the Periodontium}

Older people are more likely to be taking multiple medications to restore organ homeostasis and/or treat pathological conditions. Several medications may function as positive or negative factors on the periodontium.

Overall prevalence of hypertension increases with age consistently in all world regions [117]. Calcium channel blockers (CCBs) are drugs frequently used to reduce blood pressure. By binding to L-type calcium channels expressed on vascular smooth muscles and cardiac myocytes, CCBs lead to relaxation of vascular smooth muscles and vasodilation, which in turn lowers arterial blood pressure [118]. Interestingly, the majority of CCBs, including nifedipine, diltiazem, verapamil, and felodipine, have been reported to induce gingival enlargement or overgrowth, and gingival hyperplasia could be localized or shown in the entire mouth [119-122]. Although CCBs do not seem to directly affect the underlying alveolar bone, drug-induced gingival overgrowth may create pockets for the accumulation of pathogenic bacterial biofilm, thus inducing periodontitis and tooth loss.

In contrast, some medications used to treat other systemic diseases could provide benefits for abnormalities in the periodontium. Rheumatoid arthritis (RA) is a chronic autoinflammatory disease, resulting in synovial hyperplasia and extensive joint destruction. Although RA can arise in any age, the cumulative risk of RA increases rapidly around age 60 years, where the incidence rate of RA reaches a zenith, and flattens beyond age 80 years [123]. Rituximab is a chimeric mouse/human monoclonal antibody against the protein CD20 that is primarily expressed on the surface of B cells. Although the role of $B$ cells in the pathogenesis of RA is not precisely established, studies have shown that the administration of rituximab, alone or in combination with either cyclophosphamide or methotrexate, depleted circulating B cells and improved disease symptoms of RA for up to 1 year $[124,125]$. Coat et al. demonstrated that rituximab treatment significantly ameliorated periodontal indices, such as modified gingival index, papillary bleeding index, pocket depth and attachment loss, and delayed inflammation and bone damage [126]. Although this study did not compare the efficacy of rituximab between the young and aged group, considering that mean age of subjects in the study was over 60 years, it would be possible that rituximab may have a positive role in age-mediated pathophysiology in the periodontium.

Another example of a drug that shows potential benefits for the periodontium is metformin. Although metformin has been used as the first line pharmacotherapy against type 2 diabetes since the 1950s, metformin also showed other virtues such as AMPK-dependent anti-tumor activity [127] and anti-atherogenic functions [128]. Interestingly, metformin improved clinical outcomes in chronic periodontitis patients [129]. Metformin suppressed Porphyromonas gingivalis LPS-induced production of pro-inflammatory cytokines, including IL-1 $\beta$, IL- 6 , and TNF- $\alpha$, in human gingival fibroblasts and periodontal ligament cells through targeting NLRP3 inflammasome [130,131]. More recently, Kuang et al. demonstrated that metformin can prevent oxidative stress-induced cellular senescence by stimulating autophagy [132]. In addition, metformin positively regulates bone repair and metabolism by reversing abnormal expression of RANKL, osteopontin, TRAP expres- 
sion [133]. Furthermore, metformin shows osteogenic activity through facilitating the proliferation and differentiation of periodontal ligament stem cells [134,135].

\section{Conclusions}

The periodontium serves multiple functions in maintaining the structure of the orofacial complex, providing mastication control, and protecting the oral cavity against pathogens. Because the destruction of the periodontium is currently considered as irreversible and permanent, structural and functional maintenance of the periodontium is critical. However, these physiological roles are progressively reduced or lost with age, which leads to the increased vulnerability to numerous diseases. Aging-related intrinsic factors, including replicative stress, oxidative damages, genetic alteration, mitochondrial decline, and cellular senescence, and extrinsic factors, including changes in oral flora and medication-driven pathologies, synergistically weaken the performance of the periodontium. Therefore, understanding the effect of aging on homeostasis in the periodontium would be important to keep the oral environment and further life quality in a good condition.

Author Contributions: Conceptualization, J.-S.B. and D.-Y.K.; Writing, Y.G.K., S.M.L., S.B., T.P., H.K. (Hyeonjin Kim), Y.J., K.M., H.K. (Hyungmin Kim), K.L., J.P. and D.-Y.K.; Visualization, Y.G.K., S.M.L., J.-S.B. and D.-Y.K.; Funding Acquisition, J.-S.B. and D.-Y.K. All authors have read and agreed to the published version of the manuscript.

Funding: This work was supported by the National Research Foundation of Korea (NRF) grant funded by the Korea government (MSIT) (No.2017R1A5A2015391, and 2020R1C1C1006757). This research was also supported by the Basic Science Research Program through the National Research Foundation of Korea (NRF) funded by the Ministry of Education (No. 2019R1I1A2A01062430).

Institutional Review Board Statement: Not applicable.

Informed Consent Statement: Not applicable.

Data Availability Statement: Agree with MDPI research data policies.

Conflicts of Interest: The authors declare no conflict of interest.

\section{References}

1. Flatt, T. A new definition of aging? Front. Genet. 2012, 3, 148. [CrossRef] [PubMed]

2. Lopez-Otin, C.; Blasco, M.A.; Partridge, L.; Serrano, M.; Kroemer, G. The hallmarks of aging. Cell 2013, 153, 1194-1217. [CrossRef] [PubMed]

3. Partridge, L.; Fuentealba, M.; Kennedy, B.K. The quest to slow ageing through drug discovery. Nat. Rev. Drug Discov. 2020, 19, 513-532. [CrossRef] [PubMed]

4. Harrison, D.E.; Strong, R.; Sharp, Z.D.; Nelson, J.F.; Astle, C.M.; Flurkey, K.; Nadon, N.L.; Wilkinson, J.E.; Frenkel, K.; Carter, C.S.; et al. Rapamycin fed late in life extends lifespan in genetically heterogeneous mice. Nature 2009, 460, 392-395. [CrossRef] [PubMed]

5. Lesniewski, L.A.; Seals, D.R.; Walker, A.E.; Henson, G.D.; Blimline, M.W.; Trott, D.W.; Bosshardt, G.C.; LaRocca, T.J.; Lawson, B.R.; Zigler, M.C.; et al. Dietary rapamycin supplementation reverses age-related vascular dysfunction and oxidative stress, while modulating nutrient-sensing, cell cycle, and senescence pathways. Aging Cell 2017, 16, 17-26. [CrossRef]

6. An, J.Y.; Kerns, K.A.; Ouellette, A.; Robinson, L.; Morris, H.D.; Kaczorowski, C.; Park, S.I.; Mekvanich, T.; Kang, A.; McLean, J.S.; et al. Rapamycin rejuvenates oral health in aging mice. Elife 2020, 9. [CrossRef]

7. Majumder, S.; Caccamo, A.; Medina, D.X.; Benavides, A.D.; Javors, M.A.; Kraig, E.; Strong, R.; Richardson, A.; Oddo, S. Lifelong rapamycin administration ameliorates age-dependent cognitive deficits by reducing IL-1beta and enhancing NMDA signaling. Aging Cell 2012, 11, 326-335. [CrossRef]

8. Chung, C.L.; Lawrence, I.; Hoffman, M.; Elgindi, D.; Nadhan, K.; Potnis, M.; Jin, A.; Sershon, C.; Binnebose, R.; Lorenzini, A.; et al. Topical rapamycin reduces markers of senescence and aging in human skin: An exploratory, prospective, randomized trial. Geroscience 2019, 41, 861-869. [CrossRef]

9. Howitz, K.T.; Bitterman, K.J.; Cohen, H.Y.; Lamming, D.W.; Lavu, S.; Wood, J.G.; Zipkin, R.E.; Chung, P.; Kisielewski, A.; Zhang, L.L.; et al. Small molecule activators of sirtuins extend Saccharomyces cerevisiae lifespan. Nature 2003, 425, 191-196. [CrossRef]

10. Wood, J.G.; Rogina, B.; Lavu, S.; Howitz, K.; Helfand, S.L.; Tatar, M.; Sinclair, D. Sirtuin activators mimic caloric restriction and delay ageing in metazoans. Nature 2004, 430, 686-689. [CrossRef]

11. Baur, J.A.; Pearson, K.J.; Price, N.L.; Jamieson, H.A.; Lerin, C.; Kalra, A.; Prabhu, V.V.; Allard, J.S.; Lopez-Lluch, G.; Lewis, K.; et al. Resveratrol improves health and survival of mice on a high-calorie diet. Nature 2006, 444, 337-342. [CrossRef] [PubMed] 
12. Gerhardt, E.; Graber, S.; Szego, E.M.; Moisoi, N.; Martins, L.M.; Outeiro, T.F.; Kermer, P. Idebenone and resveratrol extend lifespan and improve motor function of HtrA2 knockout mice. PLoS ONE 2011, 6, e28855. [CrossRef] [PubMed]

13. Mancuso, R.; del Valle, J.; Modol, L.; Martinez, A.; Granado-Serrano, A.B.; Ramirez-Nunez, O.; Pallas, M.; Portero-Otin, M.; Osta R.; Navarro, X. Resveratrol improves motoneuron function and extends survival in SOD1(G93A) ALS mice. Neurotherapeutics 2014, 11, 419-432. [CrossRef]

14. Thaung Zaw, J.J.; Howe, P.R.C.; Wong, R.H.X. Sustained Cerebrovascular and Cognitive Benefits of Resveratrol in Postmenopausal Women. Nutrients 2020, 12, 828. [CrossRef] [PubMed]

15. Cabreiro, F.; Au, C.; Leung, K.Y.; Vergara-Irigaray, N.; Cocheme, H.M.; Noori, T.; Weinkove, D.; Schuster, E.; Greene, N.D.; Gems, D. Metformin retards aging in C. elegans by altering microbial folate and methionine metabolism. Cell 2013, 153, 228-239. [CrossRef] [PubMed]

16. Song, J.; Jiang, G.; Zhang, J.; Guo, J.; Li, Z.; Hao, K.; Liu, L.; Cheng, Z.; Tong, X.; Dai, F. Metformin prolongs lifespan through remodeling the energy distribution strategy in silkworm, Bombyx mori. Aging 2019, 11, 240-248. [CrossRef]

17. Wang, F.; Yang, J.; Lin, H.; Li, Q.; Ye, Z.; Lu, Q.; Chen, L.; Tu, Z.; Tian, G. Improved Human Age Prediction by Using Gene Expression Profiles From Multiple Tissues. Front. Genet. 2020, 11, 1025. [CrossRef]

18. Malamon, J.S.; Kriete, A. Erosion of Gene Co-expression Networks Reveal Deregulation of Immune System Processes in Late-Onset Alzheimer's Disease. Front. Neurosci. 2020, 14, 228. [CrossRef]

19. Wang, C.; Jurk, D.; Maddick, M.; Nelson, G.; Martin-Ruiz, C.; von Zglinicki, T. DNA damage response and cellular senescence in tissues of aging mice. Aging Cell 2009, 8, 311-323. [CrossRef]

20. Karin, O.; Agrawal, A.; Porat, Z.; Krizhanovsky, V.; Alon, U. Senescent cell turnover slows with age providing an explanation for the Gompertz law. Nat. Commun. 2019, 10, 5495. [CrossRef]

21. Kujoth, G.C.; Hiona, A.; Pugh, T.D.; Someya, S.; Panzer, K.; Wohlgemuth, S.E.; Hofer, T.; Seo, A.Y.; Sullivan, R.; Jobling, W.A.; et al. Mitochondrial DNA mutations, oxidative stress, and apoptosis in mammalian aging. Science 2005, 309, 481-484. [CrossRef] [PubMed]

22. Green, D.R.; Galluzzi, L.; Kroemer, G. Mitochondria and the autophagy-inflammation-cell death axis in organismal aging. Science 2011, 333, 1109-1112. [CrossRef] [PubMed]

23. Andrei, M.; Dinischiotu, A.; Didilescu, A.C.; Ionita, D.; Demetrescu, I. Periodontal materials and cell biology for guided tissue and bone regeneration. Ann. Anat. 2018, 216, 164-169. [CrossRef] [PubMed]

24. Luan, X.; Ito, Y.; Holliday, S.; Walker, C.; Daniel, J.; Galang, T.M.; Fukui, T.; Yamane, A.; Begole, E.; Evans, C.; et al. Extracellular matrix-mediated tissue remodeling following axial movement of teeth. J. Histochem. Cytochem. 2007, 55, 127-140. [CrossRef] [PubMed]

25. Tribble, G.D.; Lamont, R.J. Bacterial invasion of epithelial cells and spreading in periodontal tissue. Periodontology 2000 2010, 52, 68-83. [CrossRef] [PubMed]

26. Bartold, P.M.; Walsh, L.J.; Narayanan, A.S. Molecular and cell biology of the gingiva. Periodontology 2000 2000, $24,28-55$. [CrossRef] [PubMed]

27. Hormia, M.; Owaribe, K.; Virtanen, I. The dento-epithelial junction: Cell adhesion by type I hemidesmosomes in the absence of a true basal lamina. J. Periodontol. 2001, 72, 788-797. [CrossRef]

28. Hayashi, Y.; Matsunaga, T.; Yamamoto, G.; Nishii, K.; Usui, M.; Yamamoto, M.; Tachikawa, T. Comprehensive analysis of gene expression in the junctional epithelium by laser microdissection and microarray analysis. J. Periodontal Res. 2010, 45, 618-625. [CrossRef]

29. Nishii, K.; Usui, M.; Yamamoto, G.; Yajima, S.; Tsukamoto, Y.; Tanaka, J.; Tachikawa, T.; Yamamoto, M. The distribution and expression of S100A8 and S100A9 in gingival epithelium of mice. J. Periodontal Res. 2013, 48, 235-242. [CrossRef]

30. Tsukamoto, Y.; Usui, M.; Yamamoto, G.; Takagi, Y.; Tachikawa, T.; Yamamoto, M.; Nakamura, M. Role of the junctional epithelium in periodontal innate defense and homeostasis. J. Periodontal Res. 2012, 47, 750-757. [CrossRef]

31. Nakamura, M. Histological and immunological characteristics of the junctional epithelium. Jpn. Dent. Sci. Rev. 2018, 54, 59-65. [CrossRef] [PubMed]

32. Melcher, A.H. On the repair potential of periodontal tissues. J. Periodontol. 1976, 47, 256-260. [CrossRef] [PubMed]

33. Battegay, E.J.; Raines, E.W.; Seifert, R.A.; Bowen-Pope, D.F.; Ross, R. TGF-beta induces bimodal proliferation of connective tissue cells via complex control of an autocrine PDGF loop. Cell 1990, 63, 515-524. [CrossRef]

34. Schroeder, H.E.; Page, R. Lymphocyte-fibroblast interaction in the pathogenesis of inflammatory gingival disease. Experientia 1972, 28, 1228-1230. [CrossRef] [PubMed]

35. Ainamo, J.; Talari, A. The increase with age of the width of attached gingiva. J. Periodontal Res. 1976, 11, 182-188. [CrossRef]

36. Bhatia, G.; Kumar, A.; Khatri, M.; Bansal, M.; Saxena, S. Assessment of the width of attached gingiva using different methods in various age groups: A clinical study. J. Indian Soc. Periodontol. 2015, 19, 199-202. [CrossRef]

37. Schatzle, M.; Loe, H.; Burgin, W.; Anerud, A.; Boysen, H.; Lang, N.P. Clinical course of chronic periodontitis. I. Role of gingivitis. J. Clin. Periodontol. 2003, 30, 887-901. [CrossRef]

38. Caceres, M.; Oyarzun, A.; Smith, P.C. Defective Wound-healing in Aging Gingival Tissue. J. Dent. Res. 2014, 93, 691-697. [CrossRef]

39. Gonzalez, O.A.; Stromberg, A.J.; Huggins, P.M.; Gonzalez-Martinez, J.; Novak, M.J.; Ebersole, J.L. Apoptotic genes are differentially expressed in aged gingival tissue. J. Dent. Res. 2011, 90, 880-886. [CrossRef] 
40. Jiang, N.; Guo, W.; Chen, M.; Zheng, Y.; Zhou, J.; Kim, S.G.; Embree, M.C.; Songhee Song, K.; Marao, H.F.; Mao, J.J. Periodontal Ligament and Alveolar Bone in Health and Adaptation: Tooth Movement. Front. Oral Biol. 2016, 18, 1-8. [CrossRef]

41. Ren, L.M.; Wang, W.X.; Takao, Y.; Chen, Z.X. Effects of cementum-dentine junction and cementum on the mechanical response of tooth supporting structure. J. Dent. 2010, 38, 882-891. [CrossRef] [PubMed]

42. Naveh, G.R.; Lev-Tov Chattah, N.; Zaslansky, P.; Shahar, R.; Weiner, S. Tooth-PDL-bone complex: Response to compressive loads encountered during mastication-A review. Arch. Oral Biol. 2012, 57, 1575-1584. [CrossRef] [PubMed]

43. Beertsen, W.; Everts, V. Junctions between fibroblasts in mouse periodontal ligament. J. Periodontal Res. 1980, 15, 655-668. [CrossRef] [PubMed]

44. Yamaguchi, N.; Chiba, M.; Mitani, H. The induction of c-fos mRNA expression by mechanical stress in human periodontal ligament cells. Arch. Oral Biol. 2002, 47, 465-471. [CrossRef]

45. Kook, S.H.; Hwang, J.M.; Park, J.S.; Kim, E.M.; Heo, J.S.; Jeon, Y.M.; Lee, J.C. Mechanical force induces type I collagen expression in human periodontal ligament fibroblasts through activation of ERK/JNK and AP-1. J. Cell Biochem. 2009, 106, $1060-1067$. [CrossRef]

46. Wattanaroonwong, N.; Schoenmaker, T.; de Vries, T.J.; Everts, V. Oestrogen inhibits osteoclast formation induced by periodontal ligament fibroblasts. Arch. Oral Biol. 2011, 56, 212-219. [CrossRef]

47. Seo, B.M.; Miura, M.; Gronthos, S.; Bartold, P.M.; Batouli, S.; Brahim, J.; Young, M.; Robey, P.G.; Wang, C.Y.; Shi, S. Investigation of multipotent postnatal stem cells from human periodontal ligament. Lancet 2004, 364, 149-155. [CrossRef]

48. Athanassiou-Papaefthymiou, M.; Papagerakis, P.; Papagerakis, S. Isolation and Characterization of Human Adult Epithelial Stem Cells from the Periodontal Ligament. J. Dent. Res. 2015, 94, 1591-1600. [CrossRef]

49. Van der Velden, U. Effect of age on the periodontium. J. Clin. Periodontol. 1984, 11, 281-294. [CrossRef]

50. Benatti, B.B.; Silverio, K.G.; Casati, M.Z.; Sallum, E.A.; Nociti, F.H., Jr. Influence of aging on biological properties of periodontal ligament cells. Connect. Tissue Res. 2008, 49, 401-408. [CrossRef]

51. Nishimura, F.; Terranova, V.P.; Braithwaite, M.; Orman, R.; Ohyama, H.; Mineshiba, J.; Chou, H.H.; Takashiba, S.; Murayama, Y. Comparison of in vitro proliferative capacity of human periodontal ligament cells in juvenile and aged donors. Oral Dis. 1997, 3, 162-166. [CrossRef] [PubMed]

52. Benatti, B.B.; Silverio, K.G.; Casati, M.Z.; Sallum, E.A.; Nociti, F.H., Jr. Inflammatory and bone-related genes are modulated by aging in human periodontal ligament cells. Cytokine 2009, 46, 176-181. [CrossRef] [PubMed]

53. Yamaguchi, M. RANK/RANKL/OPG during orthodontic tooth movement. Orthod. Craniofac. Res. 2009, 12, 113-119. [CrossRef] [PubMed]

54. Lim, W.H.; Liu, B.; Mah, S.J.; Chen, S.; Helms, J.A. The molecular and cellular effects of ageing on the periodontal ligament. J. Clin. Periodontol. 2014, 41, 935-942. [CrossRef] [PubMed]

55. Zhang, J.; An, Y.; Gao, L.N.; Zhang, Y.J.; Jin, Y.; Chen, F.M. The effect of aging on the pluripotential capacity and regenerative potential of human periodontal ligament stem cells. Biomaterials 2012, 33, 6974-6986. [CrossRef]

56. Lossdorfer, S.; Kraus, D.; Jager, A. Aging affects the phenotypic characteristics of human periodontal ligament cells and the cellular response to hormonal stimulation in vitro. J. Periodontal Res. 2010, 45, 764-771. [CrossRef]

57. Liguori, I.; Russo, G.; Curcio, F.; Bulli, G.; Aran, L.; Della-Morte, D.; Gargiulo, G.; Testa, G.; Cacciatore, F.; Bonaduce, D.; et al. Oxidative stress, aging, and diseases. Clin. Interv. Aging 2018, 13, 757-772. [CrossRef]

58. Salisbury, D.; Bronas, U. Reactive oxygen and nitrogen species: Impact on endothelial dysfunction. Nurs. Res. 2015, 64, 53-66. [CrossRef]

59. Kong, Q.; Lin, C.L. Oxidative damage to RNA: Mechanisms, consequences, and diseases. Cell Mol. Life Sci. 2010, 67, 1817-1829. [CrossRef]

60. Radi, R. Oxygen radicals, nitric oxide, and peroxynitrite: Redox pathways in molecular medicine. Proc. Natl. Acad. Sci. USA 2018, 115, 5839-5848. [CrossRef]

61. Bredt, D.S. Nitric oxide signaling specificity-the heart of the problem. J. Cell Sci. 2003, 116, 9-15. [CrossRef] [PubMed]

62. White, C.R.; Brock, T.A.; Chang, L.Y.; Crapo, J.; Briscoe, P.; Ku, D.; Bradley, W.A.; Gianturco, S.H.; Gore, J.; Freeman, B.A.; et al. Superoxide and peroxynitrite in atherosclerosis. Proc. Natl. Acad. Sci. USA 1994, 91, 1044-1048. [CrossRef] [PubMed]

63. Mulligan, M.S.; Hevel, J.M.; Marletta, M.A.; Ward, P.A. Tissue injury caused by deposition of immune complexes is L-arginine dependent. Proc. Natl. Acad. Sci. USA 1991, 88, 6338-6342. [CrossRef] [PubMed]

64. Paxinou, E.; Chen, Q.; Weisse, M.; Giasson, B.I.; Norris, E.H.; Rueter, S.M.; Trojanowski, J.Q.; Lee, V.M.; Ischiropoulos, H. Induction of alpha-synuclein aggregation by intracellular nitrative insult. J. Neurosci. 2001, 21, 8053-8061. [CrossRef] [PubMed]

65. Laurent, M.; Lepoivre, M.; Tenu, J.P. Kinetic modelling of the nitric oxide gradient generated in vitro by adherent cells expressing inducible nitric oxide synthase. Biochem. J. 1996, 314, 109-113. [CrossRef] [PubMed]

66. Yoon, Y.; Kim, T.J.; Lee, J.M.; Kim, D.Y. SOD2 is upregulated in periodontitis to reduce further inflammation progression. Oral Dis. 2018, 24, 1572-1580. [CrossRef]

67. Tanaka, T.; Basisty, N.; Fantoni, G.; Candia, J.; Moore, A.Z.; Bioancotto, A.; Schilling, B.; Bandinelli, S.; Ferrucci, L. Plasma proteomic biomarker signature of age predicts health and life span. Elife 2020, 9. [CrossRef]

68. Amargant, F.; Manuel, S.L.; Tu, Q.; Parkes, W.S.; Rivas, F.; Zhou, L.T.; Rowley, J.E.; Villanueva, C.E.; Hornick, J.E.; Shekhawat, G.S.; et al. Ovarian stiffness increases with age in the mammalian ovary and depends on collagen and hyaluronan matrices. Aging Cell 2020, 19, e13259. [CrossRef] 
69. Stern, R.; Maibach, H.I. Hyaluronan in skin: Aspects of aging and its pharmacologic modulation. Clin. Dermatol. 2008, 26, 106-122. [CrossRef]

70. Feinberg, R.N.; Beebe, D.C. Hyaluronate in vasculogenesis. Science 1983, 220, 1177-1179. [CrossRef]

71. Yildirim, S.; Ozener, H.O.; Dogan, B.; Kuru, B. Effect of topically applied hyaluronic acid on pain and palatal epithelial wound healing: An examiner-masked, randomized, controlled clinical trial. J. Periodontol. 2018, 89, 36-45. [CrossRef] [PubMed]

72. Ansari, S.; Diniz, I.M.; Chen, C.; Sarrion, P.; Tamayol, A.; Wu, B.M.; Moshaverinia, A. Human Periodontal Ligament- and Gingiva-derived Mesenchymal Stem Cells Promote Nerve Regeneration When Encapsulated in Alginate/Hyaluronic Acid 3D Scaffold. Adv. Healthc. Mater. 2017, 6. [CrossRef] [PubMed]

73. Atkuru, S.; Muniraj, G.; Sudhaharan, T.; Chiam, K.H.; Wright, G.D.; Sriram, G. Cellular ageing of oral fibroblasts differentially modulates extracellular matrix organization. J. Periodontal Res. 2020. [CrossRef]

74. Marin, S.; Popovic-Pejicic, S.; Radosevic-Caric, B.; Trtic, N.; Tatic, Z.; Selakovic, S. Hyaluronic acid treatment outcome on the post-extraction wound healing in patients with poorly controlled type 2 diabetes: A randomized controlled split-mouth study. Med. Oral Patol. Oral Cir. Bucal 2020, 25, e154-e160. [CrossRef] [PubMed]

75. Lindhe, J.; Socransky, S.; Nyman, S.; Westfelt, E.; Haffajee, A. Effect of age on healing following periodontal therapy. J. Clin. Periodontol. 1985, 12, 774-787. [CrossRef]

76. Holm-Pedersen, P.; Loe, H. Wound healing in the gingiva of young and old individuals. Scand. J. Dent. Res. 1971, 79, 40-53. [CrossRef]

77. Kim, S.; Ahn, S.H.; Lee, J.S.; Song, J.E.; Cho, S.H.; Jung, S.; Kim, S.K.; Kim, S.H.; Lee, K.P.; Kwon, K.S.; et al. Differential Matrix Metalloprotease (MMP) Expression Profiles Found in Aged Gingiva. PLoS ONE 2016, 11, e0158777. [CrossRef]

78. Ashburner, M.; Ball, C.A.; Blake, J.A.; Botstein, D.; Butler, H.; Cherry, J.M.; Davis, A.P.; Dolinski, K.; Dwight, S.S.; Eppig, J.T.; et al. Gene ontology: Tool for the unification of biology. The Gene Ontology Consortium. Nat. Genet. 2000, 25, 25-29. [CrossRef]

79. The Gene Ontology, C. The Gene Ontology Resource: 20 years and still GOing strong. Nucleic Acids Res. 2019, 47, D330-D338. [CrossRef]

80. Mi, H.; Muruganujan, A.; Ebert, D.; Huang, X.; Thomas, P.D. PANTHER version 14: More genomes, a new PANTHER GO-slim and improvements in enrichment analysis tools. Nucleic Acids Res. 2019, 47, D419-D426. [CrossRef]

81. Raudvere, U.; Kolberg, L.; Kuzmin, I.; Arak, T.; Adler, P.; Peterson, H.; Vilo, J. g:Profiler: A web server for functional enrichment analysis and conversions of gene lists (2019 update). Nucleic Acids Res. 2019, 47, W191-W198. [CrossRef] [PubMed]

82. Reimand, J.; Kull, M.; Peterson, H.; Hansen, J.; Vilo, J. g:Profiler-a web-based toolset for functional profiling of gene lists from large-scale experiments. Nucleic Acids Res. 2007, 35, W193-W200. [CrossRef] [PubMed]

83. Beklen, A.; Tuter, G.; Sorsa, T.; Hanemaaijer, R.; Virtanen, I.; Tervahartiala, T.; Konttinen, Y.T. Gingival tissue and crevicular fluid co-operation in adult periodontitis. J. Dent. Res. 2006, 85, 59-63. [CrossRef] [PubMed]

84. Ramseier, C.A.; Kinney, J.S.; Herr, A.E.; Braun, T.; Sugai, J.V.; Shelburne, C.A.; Rayburn, L.A.; Tran, H.M.; Singh, A.K.; Giannobile, W.V. Identification of pathogen and host-response markers correlated with periodontal disease. J. Periodontol. 2009, 80, 436-446. [CrossRef] [PubMed]

85. Gursoy, U.K.; Kononen, E.; Pradhan-Palikhe, P.; Tervahartiala, T.; Pussinen, P.J.; Suominen-Taipale, L.; Sorsa, T. Salivary MMP-8, TIMP-1, and ICTP as markers of advanced periodontitis. J. Clin. Periodontol. 2010, 37, 487-493. [CrossRef] [PubMed]

86. Hernandez, M.; Valenzuela, M.A.; Lopez-Otin, C.; Alvarez, J.; Lopez, J.M.; Vernal, R.; Gamonal, J. Matrix metalloproteinase-13 is highly expressed in destructive periodontal disease activity. J. Periodontol. 2006, 77, 1863-1870. [CrossRef]

87. Hernandez Rios, M.; Sorsa, T.; Obregon, F.; Tervahartiala, T.; Valenzuela, M.A.; Pozo, P.; Dutzan, N.; Lesaffre, E.; Molas, M.; Gamonal, J. Proteolytic roles of matrix metalloproteinase (MMP)-13 during progression of chronic periodontitis: Initial evidence for MMP-13/MMP-9 activation cascade. J. Clin. Periodontol. 2009, 36, 1011-1017. [CrossRef]

88. Franco, C.; Patricia, H.R.; Timo, S.; Claudia, B.; Marcela, H. Matrix Metalloproteinases as Regulators of Periodontal Inflammation. Int. J. Mol. Sci. 2017, 18, 440. [CrossRef]

89. Kuula, H.; Salo, T.; Pirila, E.; Tuomainen, A.M.; Jauhiainen, M.; Uitto, V.J.; Tjaderhane, L.; Pussinen, P.J.; Sorsa, T. Local and systemic responses in matrix metalloproteinase 8-deficient mice during Porphyromonas gingivalis-induced periodontitis. Infect. Immun. 2009, 77, 850-859. [CrossRef]

90. Hernandez, M.; Gamonal, J.; Salo, T.; Tervahartiala, T.; Hukkanen, M.; Tjaderhane, L.; Sorsa, T. Reduced expression of lipopolysaccharide-induced CXC chemokine in Porphyromonas gingivalis-induced experimental periodontitis in matrix metalloproteinase-8 null mice. J. Periodontal Res. 2011, 46, 58-66. [CrossRef]

91. Van Lint, P.; Wielockx, B.; Puimege, L.; Noel, A.; Lopez-Otin, C.; Libert, C. Resistance of collagenase-2 (matrix metalloproteinase8)-deficient mice to TNF-induced lethal hepatitis. J. Immunol. 2005, 175, 7642-7649. [CrossRef] [PubMed]

92. Weng, H.; Yan, Y.; Jin, Y.H.; Meng, X.Y.; Mo, Y.Y.; Zeng, X.T. Matrix metalloproteinase gene polymorphisms and periodontitis susceptibility: A meta-analysis involving 6,162 individuals. Sci. Rep. 2016, 6, 24812. [CrossRef] [PubMed]

93. Li, D.; Cai, Q.; Ma, L.; Wang, M.; Ma, J.; Zhang, W.; Pan, Y.; Wang, L. Association between MMP-1 g.-1607dupG polymorphism and periodontitis susceptibility: A meta-analysis. PLoS ONE 2013, 8, e59513. [CrossRef] [PubMed]

94. Warde-Farley, D.; Donaldson, S.L.; Comes, O.; Zuberi, K.; Badrawi, R.; Chao, P.; Franz, M.; Grouios, C.; Kazi, F.; Lopes, C.T.; et al. The GeneMANIA prediction server: Biological network integration for gene prioritization and predicting gene function. Nucleic Acids Res. 2010, 38, W214-W220. [CrossRef] [PubMed] 
95. Grzibovskis, M.; Urtane, I.; Pilmane, M. Specific signaling molecule expression in periodontal ligaments in different age groups: Pilot study. Stomatologija 2011, 13, 117-122.

96. Tanimoto, K.; Ohkuma, S.; Tanne, Y.; Kunimatsu, R.; Hirose, N.; Mitsuyoshi, T.; Yoshimi, Y.; Su, S.; Tanne, K. Effects of bFGF on the Modulation of Apoptosis in Gingival Fibroblasts with Different Host Ages. Int. J. Dent. 2013, 2013, 619580. [CrossRef]

97. An, S.; Huang, X.; Gao, Y.; Ling, J.; Huang, Y.; Xiao, Y. FGF-2 induces the proliferation of human periodontal ligament cells and modulates their osteoblastic phenotype by affecting Runx2 expression in the presence and absence of osteogenic inducers. Int. J. Mol. Med. 2015, 36, 705-711. [CrossRef]

98. Fujihara, C.; Kanai, Y.; Masumoto, R.; Kitagaki, J.; Matsumoto, M.; Yamada, S.; Kajikawa, T.; Murakami, S. Fibroblast growth factor-2 inhibits CD40-mediated periodontal inflammation. J. Cell Physiol. 2019, 234, 7149-7160. [CrossRef]

99. Kitamura, M.; Nakashima, K.; Kowashi, Y.; Fujii, T.; Shimauchi, H.; Sasano, T.; Furuuchi, T.; Fukuda, M.; Noguchi, T.; Shibutani, T.; et al. Periodontal tissue regeneration using fibroblast growth factor-2: Randomized controlled phase II clinical trial. PLoS ONE 2008, 3, e2611. [CrossRef]

100. Kitamura, M.; Akamatsu, M.; Machigashira, M.; Hara, Y.; Sakagami, R.; Hirofuji, T.; Hamachi, T.; Maeda, K.; Yokota, M.; Kido, J.; et al. FGF-2 stimulates periodontal regeneration: Results of a multi-center randomized clinical trial. J. Dent. Res. 2011, 90, 35-40. [CrossRef]

101. Kitamura, M.; Akamatsu, M.; Kawanami, M.; Furuichi, Y.; Fujii, T.; Mori, M.; Kunimatsu, K.; Shimauchi, H.; Ogata, Y.; Yamamoto, M.; et al. Randomized Placebo-Controlled and Controlled Non-Inferiority Phase III Trials Comparing Trafermin, a Recombinant Human Fibroblast Growth Factor 2, and Enamel Matrix Derivative in Periodontal Regeneration in Intrabony Defects. J. Bone Miner. Res. 2016, 31, 806-814. [CrossRef] [PubMed]

102. Cochran, D.L.; Oh, T.J.; Mills, M.P.; Clem, D.S.; McClain, P.K.; Schallhorn, R.A.; McGuire, M.K.; Scheyer, E.T.; Giannobile, W.V.; Reddy, M.S.; et al. A Randomized Clinical Trial Evaluating rh-FGF-2/beta-TCP in Periodontal Defects. J. Dent. Res. 2016, 95, 523-530. [CrossRef] [PubMed]

103. Fadok, V.A.; Bratton, D.L.; Konowal, A.; Freed, P.W.; Westcott, J.Y.; Henson, P.M. Macrophages that have ingested apoptotic cells in vitro inhibit proinflammatory cytokine production through autocrine/paracrine mechanisms involving TGF-beta, PGE2, and PAF. J. Clin. Investig. 1998, 101, 890-898. [CrossRef] [PubMed]

104. Kim, S.; Elkon, K.B.; Ma, X. Transcriptional suppression of interleukin-12 gene expression following phagocytosis of apoptotic cells. Immunity 2004, 21, 643-653. [CrossRef]

105. Yilmaz, O.; Jungas, T.; Verbeke, P.; Ojcius, D.M. Activation of the phosphatidylinositol 3-kinase/Akt pathway contributes to survival of primary epithelial cells infected with the periodontal pathogen Porphyromonas gingivalis. Infect. Immun. 2004, 72, 3743-3751. [CrossRef]

106. Shoemark, D.K.; Allen, S.J. The microbiome and disease: Reviewing the links between the oral microbiome, aging, and Alzheimer's disease. J. Alzheimers Dis. 2015, 43, 725-738. [CrossRef]

107. Wu, Y.; Dong, G.; Xiao, W.; Xiao, E.; Miao, F.; Syverson, A.; Missaghian, N.; Vafa, R.; Cabrera-Ortega, A.A.; Rossa, C., Jr.; et al. Effect of Aging on Periodontal Inflammation, Microbial Colonization, and Disease Susceptibility. J. Dent. Res. 2016, 95, 460-466. [CrossRef]

108. Kang, W.; Jia, Z.; Tang, D.; Zhao, X.; Shi, J.; Jia, Q.; He, K.; Feng, Q. Time-Course Transcriptome Analysis for Drug Repositioning in Fusobacterium nucleatum-Infected Human Gingival Fibroblasts. Front. Cell Dev. Biol. 2019, 7, 204. [CrossRef]

109. Domon, H.; Tabeta, K.; Nakajima, T.; Yamazaki, K. Age-related alterations in gene expression of gingival fibroblasts stimulated with Porphyromonas gingivalis. J. Periodontal Res. 2014, 49, 536-543. [CrossRef]

110. Ahn, S.H.; Chun, S.; Park, C.; Lee, J.H.; Lee, S.W.; Lee, T.H. Transcriptome profiling analysis of senescent gingival fibroblasts in response to Fusobacterium nucleatum infection. PLoS ONE 2017, 12, e0188755. [CrossRef]

111. Patini, R.; Staderini, E.; Lajolo, C.; Lopetuso, L.; Mohammed, H.; Rimondini, L.; Rocchetti, V.; Franceschi, F.; Cordaro, M.; Gallenzi, P. Relationship between oral microbiota and periodontal disease: A systematic review. Eur. Rev. Med. Pharmacol. Sci. 2018, 22, 5775-5788. [CrossRef] [PubMed]

112. Ship, J.A.; Nolan, N.E.; Puckett, S.A. Longitudinal analysis of parotid and submandibular salivary flow rates in healthy, differentaged adults. J. Gerontol. A Biol. Sci. Med. Sci. 1995, 50, M285-M289. [CrossRef] [PubMed]

113. Percival, R.S.; Challacombe, S.J.; Marsh, P.D. Flow rates of resting whole and stimulated parotid saliva in relation to age and gender. J. Dent. Res. 1994, 73, 1416-1420. [CrossRef] [PubMed]

114. Choi, J.S.; Park, I.S.; Kim, S.K.; Lim, J.Y.; Kim, Y.M. Analysis of age-related changes in the functional morphologies of salivary glands in mice. Arch. Oral Biol. 2013, 58, 1635-1642. [CrossRef] [PubMed]

115. Azevedo, L.R.; Damante, J.H.; Lara, V.S.; Lauris, J.R. Age-related changes in human sublingual glands: A post mortem study. Arch. Oral Biol. 2005, 50, 565-574. [CrossRef]

116. Lamster, I.B.; Asadourian, L.; Del Carmen, T.; Friedman, P.K. The aging mouth: Differentiating normal aging from disease. Periodontology 2000 2016, 72, 96-107. [CrossRef]

117. Kearney, P.M.; Whelton, M.; Reynolds, K.; Muntner, P.; Whelton, P.K.; He, J. Global burden of hypertension: Analysis of worldwide data. Lancet 2005, 365, 217-223. [CrossRef]

118. Livada, R.; Shiloah, J. Calcium channel blocker-induced gingival enlargement. J. Hum. Hypertens. 2014, 28, 10-14. [CrossRef]

119. Miller, C.S.; Damm, D.D. Incidence of verapamil-induced gingival hyperplasia in a dental population. J. Periodontol. 1992, 63, 453-456. [CrossRef] 
120. Barak, S.; Engelberg, I.S.; Hiss, J. Gingival hyperplasia caused by nifedipine. Histopathologic findings. J. Periodontol. 1987, 58, 639-642. [CrossRef]

121. Lombardi, T.; Fiore-Donno, G.; Belser, U.; Di Felice, R. Felodipine-induced gingival hyperplasia: A clinical and histologic study. J. Oral Pathol. Med. 1991, 20, 89-92. [CrossRef] [PubMed]

122. Marshall, R.I.; Bartold, P.M. A clinical review of drug-induced gingival overgrowths. Aust. Dent. J. 1999, 44, 219-232. [CrossRef] [PubMed]

123. Crowson, C.S.; Matteson, E.L.; Myasoedova, E.; Michet, C.J.; Ernste, F.C.; Warrington, K.J.; Davis, J.M., 3rd; Hunder, G.G.; Therneau, T.M.; Gabriel, S.E. The lifetime risk of adult-onset rheumatoid arthritis and other inflammatory autoimmune rheumatic diseases. Arthritis Rheum. 2011, 63, 633-639. [CrossRef] [PubMed]

124. Panayi, G.S. B cells: A fundamental role in the pathogenesis of rheumatoid arthritis? Rheumatology 2005, 44 (Suppl. 2), ii3-ii7. [CrossRef]

125. Edwards, J.C.; Szczepanski, L.; Szechinski, J.; Filipowicz-Sosnowska, A.; Emery, P.; Close, D.R.; Stevens, R.M.; Shaw, T. Efficacy of B-cell-targeted therapy with rituximab in patients with rheumatoid arthritis. N. Engl. J. Med. 2004, 350, 2572-2581. [CrossRef] [PubMed]

126. Coat, J.; Demoersman, J.; Beuzit, S.; Cornec, D.; Devauchelle-Pensec, V.; Saraux, A.; Pers, J.O. Anti-B lymphocyte immunotherapy is associated with improvement of periodontal status in subjects with rheumatoid arthritis. J. Clin. Periodontol. 2015, 42, 817-823. [CrossRef] [PubMed]

127. Zakikhani, M.; Dowling, R.; Fantus, I.G.; Sonenberg, N.; Pollak, M. Metformin is an AMP kinase-dependent growth inhibitor for breast cancer cells. Cancer Res. 2006, 66, 10269-10273. [CrossRef]

128. Hattori, Y.; Suzuki, K.; Hattori, S.; Kasai, K. Metformin inhibits cytokine-induced nuclear factor kappaB activation via AMPactivated protein kinase activation in vascular endothelial cells. Hypertension 2006, 47, 1183-1188. [CrossRef]

129. Pradeep, A.R.; Nagpal, K.; Karvekar, S.; Patnaik, K.; Naik, S.B.; Guruprasad, C.N. Platelet-rich fibrin with 1\% metformin for the treatment of intrabony defects in chronic periodontitis: A randomized controlled clinical trial. J. Periodontol. 2015, 86, 729-737. [CrossRef]

130. Kang, W.; Wang, T.; Hu, Z.; Liu, F.; Sun, Y.; Ge, S. Metformin Inhibits Porphyromonas gingivalis Lipopolysaccharide-Influenced Inflammatory Response in Human Gingival Fibroblasts via Regulating Activating Transcription Factor-3 Expression. J. Periodontol. 2017, 88, e169-e178. [CrossRef]

131. Tan, Y.; Chen, J.; Jiang, Y.; Chen, X.; Li, J.; Chen, B.; Gao, J. The anti-periodontitis action of metformin via targeting NLRP3 inflammasome. Arch. Oral Biol. 2020, 114, 104692. [CrossRef] [PubMed]

132. Kuang, Y.; Hu, B.; Feng, G.; Xiang, M.; Deng, Y.; Tan, M.; Li, J.; Song, J. Metformin prevents against oxidative stress-induced senescence in human periodontal ligament cells. Biogerontology 2020, 21, 13-27. [CrossRef] [PubMed]

133. Malta, F.S.; Garcia, R.P.; Azarias, J.S.; Ribeiro, G.; Miranda, T.S.; Shibli, J.A.; Bastos, M.F. Impact of hyperglycemia and treatment with metformin on ligature-induced bone loss, bone repair and expression of bone metabolism transcription factors. PLoS ONE 2020, 15, e0237660. [CrossRef] [PubMed]

134. Zhang, R.; Liang, Q.; Kang, W.; Ge, S. Metformin facilitates the proliferation, migration, and osteogenic differentiation of periodontal ligament stem cells in vitro. Cell Biol. Int. 2019. [CrossRef]

135. Jia, L.; Xiong, Y.; Zhang, W.; Ma, X.; Xu, X. Metformin promotes osteogenic differentiation and protects against oxidative stress-induced damage in periodontal ligament stem cells via activation of the Akt/Nrf2 signaling pathway. Exp. Cell Res. 2020, 386, 111717. [CrossRef] [PubMed] 